\title{
Petition prompts backlash against scientists
}

Paris. The front pages of every French newspaper were covered last week by an outpouring of public anger against a petition from 98 researchers, physicians and public health workers asking President François Mitterrand to pardon four doctors convicted in the recent HIV-contaminated blood affair (see Nature 367, 206; 1994).

This protest against what is being widely perceived as a closing of ranks by scientists and physicians has revealed how much damage the affair has inflicted on public trust in the biomedical community. Maxine Schwartz, director of the Pasteur Institute, describes the public's reaction as a "crystallization of the problem between science and society".

Haemophiliac groups condemned the petition as "shocking", and the Professional Association of Magistrates said it was "an insult to the victims." Michel Rocard, leader

\section{New charges in HIV blood affair}

Paris. Last week's petition for an amnesty for those convicted in the HIV-contaminated blood affair in the mid-1980s (see above) coincided with a new wave of legal proceedings against individuals involved.

A 19-year-old haemophiliac, Ludovic Bouchet, has brought poisoning charges against three former ministers: Laurent Fabius, then prime minister, Georgina Dufoix, minister of social affairs, and Edmond Hervé, secretary of state for health.

Related charges are also being brought against François Gros, an adviser to Fabius and former director of the Pasteur Institute; Charles-Henri Filippi, director of Dufoix's cabinet; Gaston Rimareix, the director of Hervé's cabinet; Claude Weissenberg, an adviser to Hervé; Bahman Habibi, director of France's national blood transfusion centre at the Saint Antoine Hospital in Paris; and Jean-Baptiste Brunet, director of the European AIDS centre.

The charges have coincided with the introduction of a reform of the High Court of Justice that allows the prosecution of former ministers (see Nature 364, 269; 1993).

"I have done my best over the past 13 years to fight AIDS," says Brunet. "It's horrible for me to be charged with taking part in the epidemic." He says the charges against him are based on memoranda written to the government alerting them to the risk from contaminated blood, which are now being interpreted as indicators of his guilt, as he knew what was happening. "Of course I knew," says Brunet. "That's why I wrote the letters."

D. B. of the Socialist party said he was "astonished and worried" by the scientists' action.

A co-discoverer of HIV, Françoise BarréSinoussi, was one of the two main signatories of the letter. She has argued that the version of events in 1984-85 given by the media and during the trial "bore no relation" to the reality facing scientists at the time.

But two of the other co-discoverers Jean-Claude Chermann and Luc Montagnier - refused to sign the petition. Chermann said that "a scientist must be responsible by his acts and words", describing JeanPierre Allain, the former official at the $\mathrm{Na}$ tional Blood Transfusion Centre who was given a four-year jail sentence (two of which were suspended) as a scientist who "fully knew" that the products were contaminated.

The newspaper Le Figaro pointed out that "the central core" of the signatories about 20 in number - - work or have worked at the Pasteur Institute. It suggested that they were "closely or distantly" involved in the commercialization of the controversial French AIDS test.

It went on to identify the second major group of signatories as former officials at the French National Blood Transfusion Centre, and described foreign signatories as "friends of Allain".

Jean-Claude Gluckmann, the second main signatory of the petition, admits that the initiative backfired. But he defends it as well-intentioned. "We hoped that people would re-examine the problem more calmly than during the trial and realize that things were not so simple. We got the opposite effect to what we wanted. The petition was not against the victims, but we cannot repair an ordeal by an injustice," he says.

Jean-Baptiste Brunet, the director of the European AIDS Centre and a signatory to the petition, says Gluckmann made a mistake by sending it to the news agency Agence France Presse. "It was like a fire that he could not stop, it exploded in his hands," says Brunet. "You have to be prudent; a lot of people's lives are involved in this story."

Brunet says that he signed the letter to protest at the way in which the four who were convicted had been made scapegoats. "France has tried to avoid the fact that the responsibility was wider," he says, claiming that Allain's conviction in particular was unjust. "They needed [to charge] a doctor, and they found one."

Brunet, who himself now faces charges of "poisoning" (see below), claims that the French press, government and public has turned a blind eye to many questions unanswered by the blood trial, which concerned only contamination of clotting factors.

France was not the slowest country to introduce measures to prevent contamination of blood by HIV. But there is evidence that in France the risks were known and deliberately ignored for industrial and commercial reasons.

First, there is the question of contamination by whole blood (see Nature 364, 260; 1993). Government officials are alleged to have delayed approval of a US AIDS test for five months in 1995 to allow a French test to be released first (see Nature 353, 197; 1991). But, despite supporting evidence, the claims have never been closely examined.

Second, health officials collected blood from high-risk populations (drug addicts) in prisons until 1986, in spite of being aware of the risks. The impact of this neglect can be estimated from the fact that more than 1,300 people in France were contaminated by HIV through whole-blood transfusions, whereas fewer than a hundred were infected in the United Kingdom, where obligatory screening for HIV was introduced two months later than in France.

Whatever the outcome of the latest developments, the public's perception that a reluctance in the scientific community to take up the haemophiliacs' cause was tantamount to complicity has been further reinforced by the petitions. And, as the newspaper Libération put it, referring to the recent approval by the Senate of new bioethics laws: "Placing the bar of scientific responsibility too low is an invitation to others to set it higher."

Declan Butler

\section{French academy backs the use of English}

Paris. The French Academy of Sciences last week defended the right of French researchers to publish and present their results in English, and said it opposed any legislation that would restrict this right.

$A$ bill on the use of the French language is due to be introduced into the National Assembly in spring, and is expected to require scientists to use the French language at conferences both inside and outside France, as well as introducing other curbs on the use of English.
The academy's decision to go public with its opposition is thought to have been prompted by the lack of response from the government to similar recommendations which academy officials made privately last September.

In its statement, the academy also encourages researchers to publish books and articles in French, to meet the needs of students and others interested in science, and promote scientific culture in the French-speaking world. 